\title{
USE OF 3D PROCESS-BASED MODEL TO DETERMINE FORESTS PROTECTING AGAINST ROCKFALL - CASE STUDY KAMNISKA BISTRICA
}

UPORABA 3D PROCESNEGA MODELAZA DOLOCITEV GOZDOV, KI VARUJEJO PRED SKALNIMI PODORI - PRIMER KAMNISKE BISTRICE

Mitja Skudnik, Gal Kušar

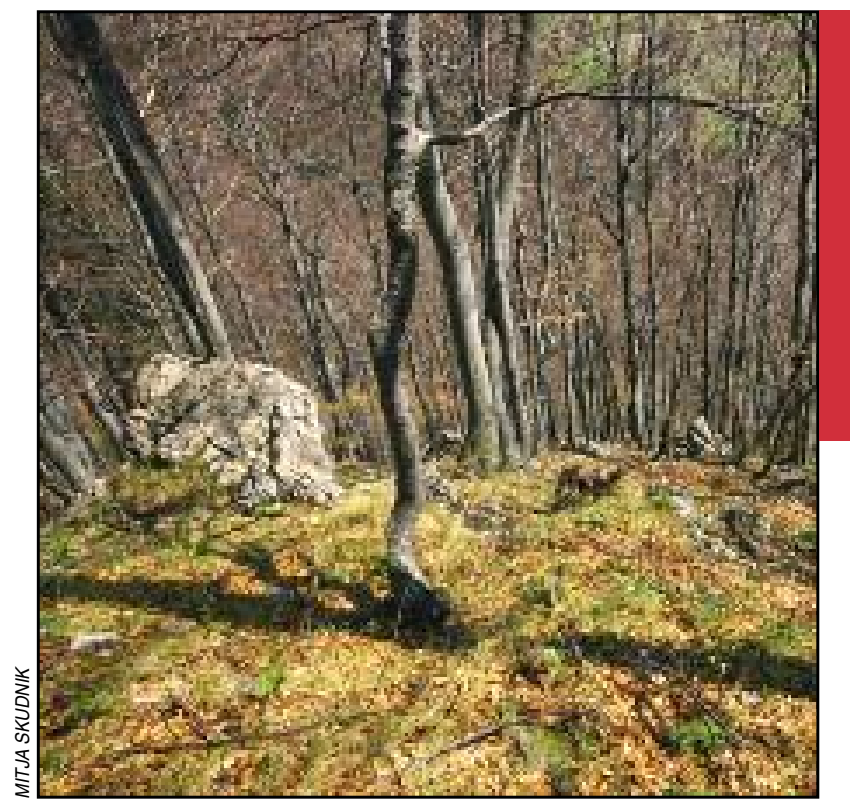

Protective forests in Slovenian Alps.

Varovalni gozdovi v Slovenskih Alpah. 


\title{
Use of 3D process-based model to determine forests protecting against rockfall - case study Kamniška Bistrica
}

\author{
DOI: $10.3986 / A G S 51202$ \\ UDC: $630 * 26: 551.435 .62(497.451)$ \\ 004.9:630*26(497.451)
}

COBISS: 1.01

\begin{abstract}
This case study of the Kamniška Bistrica forest management unit presents a 3D process-based model for determining forests protecting against rockfall. Modelling was performed using the ArcGIS 9.3.1 tool; the kinetic energy of rockfalls was calculated using the Conefall friction model. The finished map of protective forests was compared with the map of protective functions of forests, made by the Slovenia Forest Service. The protective function map covers $90 \%$ of forests classified in the $1^{\text {st }}$ category forests by the modelled map. Taking into consideration the entire forest area in the forest management unit, the maps match in $48 \%$ of cases. The differences appear predominantly in higher altitudes where the protective function map includes dwarf pine sites, and in lower altitudes where the map does not consider the possibility that trees can perform their protective functions where the terrain becomes level. The aim of this article is to draw attention to the possibilities of using the models as tools for determining forests protecting against rockfalls.
\end{abstract}

KEY WORDS: forestry, physical geography, 3D process-based modelling, protective function of forests, rockfalls, Kamniška Bistrica

The article was submitted for publication on February 17, 2011.

\section{ADDRESSES}

Mitja Skudnik, B. Sc.

Slovenian Forestry Institute

Večna pot 2, SI - 1000 Ljubljana, Slovenia

E-mail: mitja.skudnik@gozdis.si
Gal Kušar, Ph. D.

Slovenian Forestry Institute

Večna pot 2, SI - 1000 Ljubljana, Slovenia

E-mail: gal.kusar@gozdis.si

\section{Contents}

1 Introduction 255

1.1 Rockfalls and protective function of forests 255

1.2 Methods of determining protective function of forests 255

1.2.1 Modelling in GIS environment 255

2 Working methods 256

2.1 Test area presentation 256

2.2 Modelling and mapping 257

2.2.1 Preparation of data layers 257

2.2.2 Modelling 257

3 Results 262

3.1 Modelled map of protective forests 262

3.2 Comparison and analysis of differences between protective function map by SFS and modelled map of protective forests 263

4 Conclusion 264

5 Acknowledgement 264

6 References 265 


\section{Introduction}

\subsection{Rockfalls and Protective Function of Forests}

Areas with diverse relief often experience dangerous phenomena (torrent floods, avalanches, earth flows and landslides, debris flows, rock avalanches and rockfalls) that limit activities and endanger property (Brilly et al. 1999; Horvat et al. 2005; Zorn 2002; Dorren, Seijmonsbergen 2003; Kunc 2008). This article deals only with rockfalls in which the concept of »rockfall« is understood similarly to Zorn's (2002) use, in the broad sense of the word and including all kinds of breaks (from minor crumbling of small stones to major breaks of individual rocks) of solid rock on the slopes where the material freely falls towards the foot regardless of the quantity of the relocated material.

Technical measures (safety nets and catch fences) are the most common means of protection against rockfalls. However, the realization of such measures and their maintenance is expensive (Dorren 2003); such facilities represent foreign objects in the natural environment, affect natural processes in ecosystems and disrupt the aesthetics of the landscape. The forest can replace technical measures, since it represents a barrier for rockfalls. The level of success of a forest's protection depends on its structure, tree species, development phase, undergrowth, quantity and the distribution and structure of deadwood (Dorren 2006; Stoffel 2006). The enhancement of the protective function of a forest can be affected by appropriate forest management measures, e.g. leaving high stumps or regulating stand structure (ZGS OE Ljubljana 2009). Due to the costs of such measures, it makes sense to carry out these measures only on locations where the protective function is given or truly needed. The following conditions must be met:

- Property that must be protected;

- Possibility of a dangerous phenomenon that can endanger the property;

- Forest that can protect the property.

\subsection{Methods of Determining Protective Function of Forests}

The Regulation on the forest management and silviculture plans (1998) and Regulation amending the Regulation (2010) (Regulation ... 2010) differentiates between forests performing protective functions and forests performing the functions of forest land and stand protection. This article deals with both functions jointly under the term "protective function", which is understood as every forest role protecting property from rockfall.

The mapping of these functions is performed by employees of the Slovenia Forest Service (hereinafter referred to as SFS) on the basis of the Regulation ... (2010) and instructions from the Manual for Making Forest Management Plans (SFS 2008) comprising measures for determining functions regarding diverse emphasis levels. The main criteria for protective function evaluation are: defined forest associations, steep slopes, rockiness, erodible and slide-prone parent material; for the shielding function: steep slopes/high inclinations, and the presence of infrastructure, residential or economic facilities. While determining the $1^{\text {st }}$ level of protective function emphasis, we must also bear in mind protective forests, classified by the Regulation on protective forests and forests with a special purpose (Regulation ... 2005).

\subsubsection{Modelling in the GIS Environment}

Models were developed for determining areas where rockfalls can appear (Guzzetti et al. 2002; Agliardi, Crosta 2003; Marquínez et al. 2003; Zorn and Komac 2004; Petje et al. 2005; Stoffel 2006). Petje et al. (2005) classify them as dispositional and process ones, while Dorren (2003) classifies them as empirical or static, process-based and those which are based on the use of geographic information systems (hereinafter referred to as GIS) or »GIS-based « ones. Dispositional models are used for determining the point of origin of a rockfall, while the process-based models are used for determining the path of rock mass movement.

In recent years, more accurate geocoded data layers have enabled the use of three-dimensional models (hereinafter referred to as 3D), where the available raster and vector data layers are primarily applied, and the aforementioned process models are used for motion path calculation.

Despite the set mapping scales (SFS 2008), the current methods of function mapping appear to be too subjective, since they are based on a field mapping method that depends on the experience and knowledge of individual registrars. 
The aim of this article is to present the method of the 3D process model, modified according to the model, developed in the framework of the EU project ProAlp (Duc et al. 2007), which can help forestry profession in mapping protective function of forests.

\section{Working methods}

\subsection{Presentation of the Test Area}

The Kamniška Bistrica forest management unit (hereinafter referred to as FMU, in the maps GGE) is situated in the north of Slovenia, its area is 6,108 ha, 4,283 ha (70\%) of which is covered by forests (MKGP 2010). The central part of the unit comprises the upper valley of the Kamniška Bistrica River with its torrential effluent's, situated in the Kamniške Alpe area; its characteristics are steep slopes, narrow valleys, numerous dikes, and intense rockiness (SFS OU Ljubljana 2009).

SFS determined the $1^{\text {st }}$ level protective function on 3,957 ha of forest area. The protective function of the $1^{\text {st }}$ emphasis level is performed by the forests on an area of $43 \mathrm{ha}$, on steep western slopes above the 2-km segment of the Kamniška Bistrica road, from the southern FMU border towards the bottom station of the cable car to Velika planina (Figure 1) (SFS OU Ljubljana 2009). The majority of the infrastructure is located outside the areas for which the $1^{\text {st }}$ level of the protective function is determined.

Past major natural disasters are known to have occurred in the FMU. Gams and Bat (1983) mention a rockfall below Čmaževški Turn, which scattered the rocks over hundred meters across the alluvial fan; some rocks jumped over patches of forest and became stuck several tens of meters away of the slope bottom. Due to a short but intense rainfall, torrents rose in November 1990 and Kamniška Bistrica flooded. Forty-eight residential facilities were damaged in the Kamniška Bistrica upper river basin due to torrents or landslides (Repolusk 1991) on that occasion.

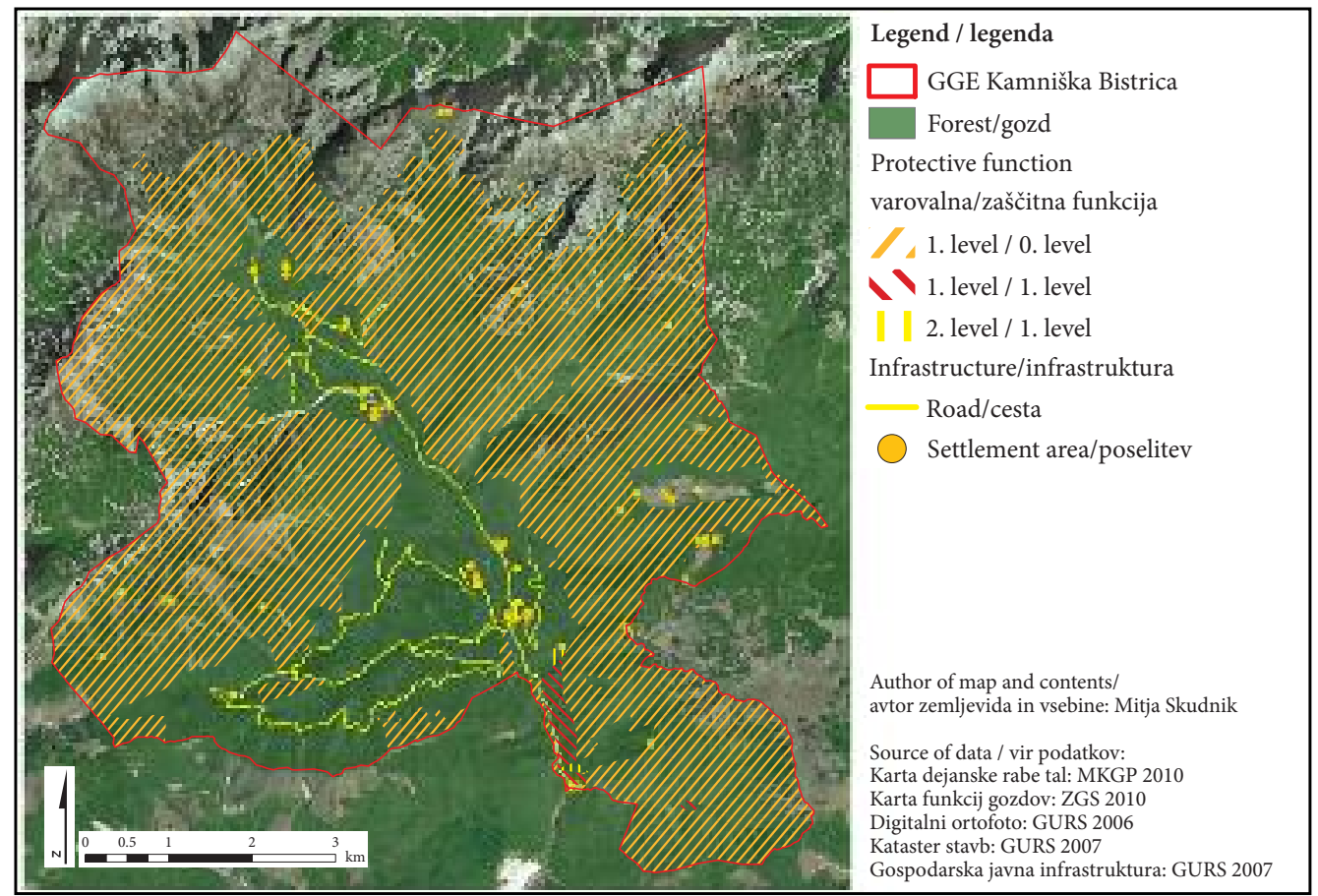

Figure 1: Protective function of the forest in the Kamniška Bistrica forest management unit. 


\subsection{Modelling and mapping}

\subsubsection{Preparation of Data Layers}

The modelling procedure was performed with the ArcGIS 9.3.1 (ESRI 2010) software. Six geocoded data layers were included in the model:

- digital height model with an accuracy of $12.5 \mathrm{~m}$ (hereinafter referred to as DHM12.5) (GURS 2005),

- rockiness map made from the Slovenia's topographic map with a scale of 1:50,000 (GURS 1999). The layer presents road lines and verges and rock areas,

- road map from the joint cadastre of public infrastructure for economic purposes (hereinafter referred to as the PIEP Building cadastre) (GURS 2007b),

- cadastre of buildings on May 25, 2007 (GURS 2007a),

- basic geological map of Slovenia with a scale of 1:100,000 (GeoZS 2003),

- map of actual land use in 2010 (MKGP 2010).

Mapping of the rockfall reach was performed applying the Conefall software (Jaboyedoff 2003), chosen for its simplicity of use, enabling application of digital height models of diverse accuracies and having no limits regarding the size of the test area.

\subsubsection{Modelling}

A modelled map of protective forests against rockfalls was made according to a 3D process-based model, composed of three complexes:

- dispositional model resulting in a map of rockfall activation areas,

- frictional model resulting in a map of damage potential,

- motion path model resulting in a modelled map of protective forests.

The aim of the dispositional model is to determine possible areas of rockfall activation, using existing geocoded data layers.

DHV12.5 represents the basic data layer of the model. Roads were deleted from the map showing road lines and rocks; thus, the map of rocks was made. Bare rock slopes with inclinations of $43^{\circ}$ or more (Dorren et al. 2005) and areas, covered by forests, with inclinations of $39^{\circ}$ or more (Duc et al. 2007) were

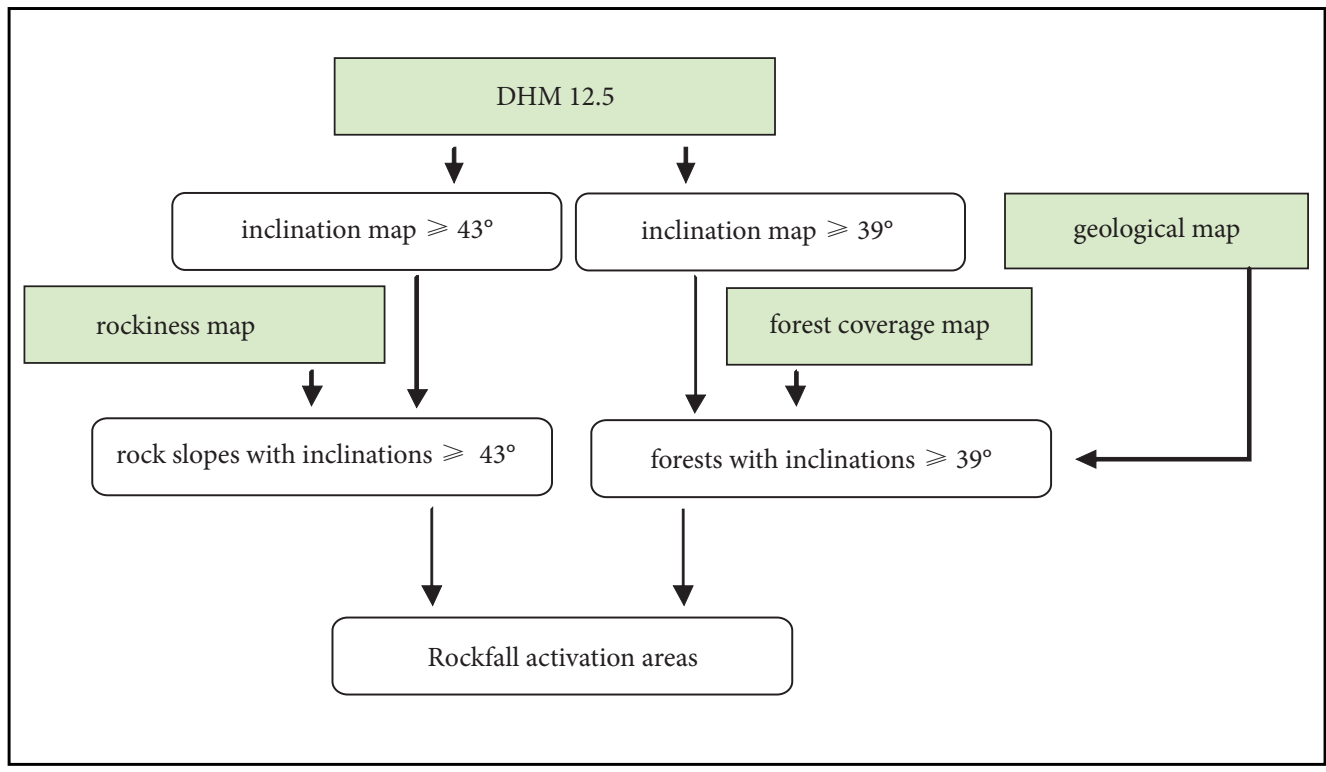

Figure 2: Process of rockfall activation area determination 


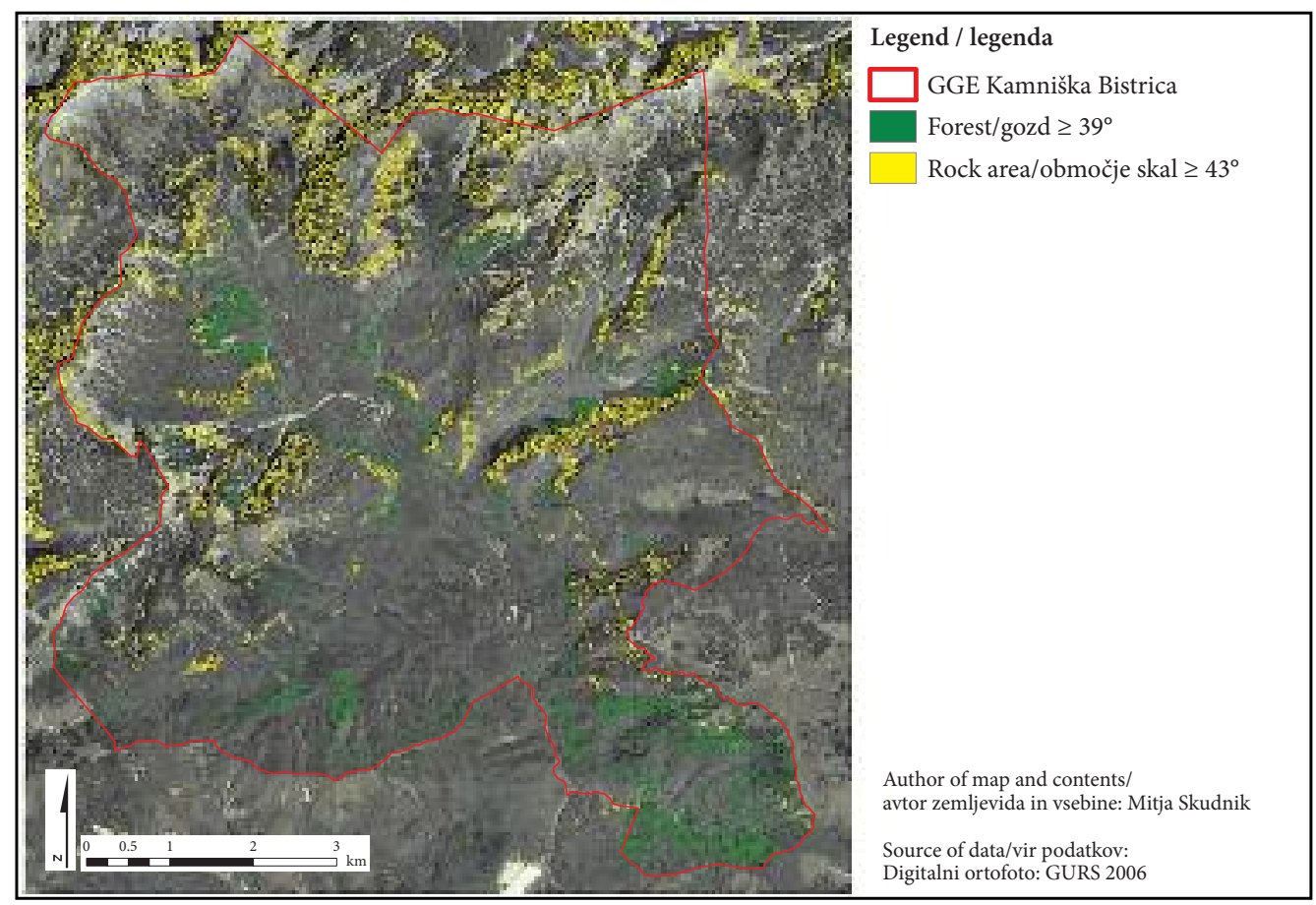

Figure 3: Map of rockfall activation areas. Rock areas with inclination of $43^{\circ}$ and more (yellow) and forests with inclinations of $39^{\circ}$ and more on unstable parental material (green).

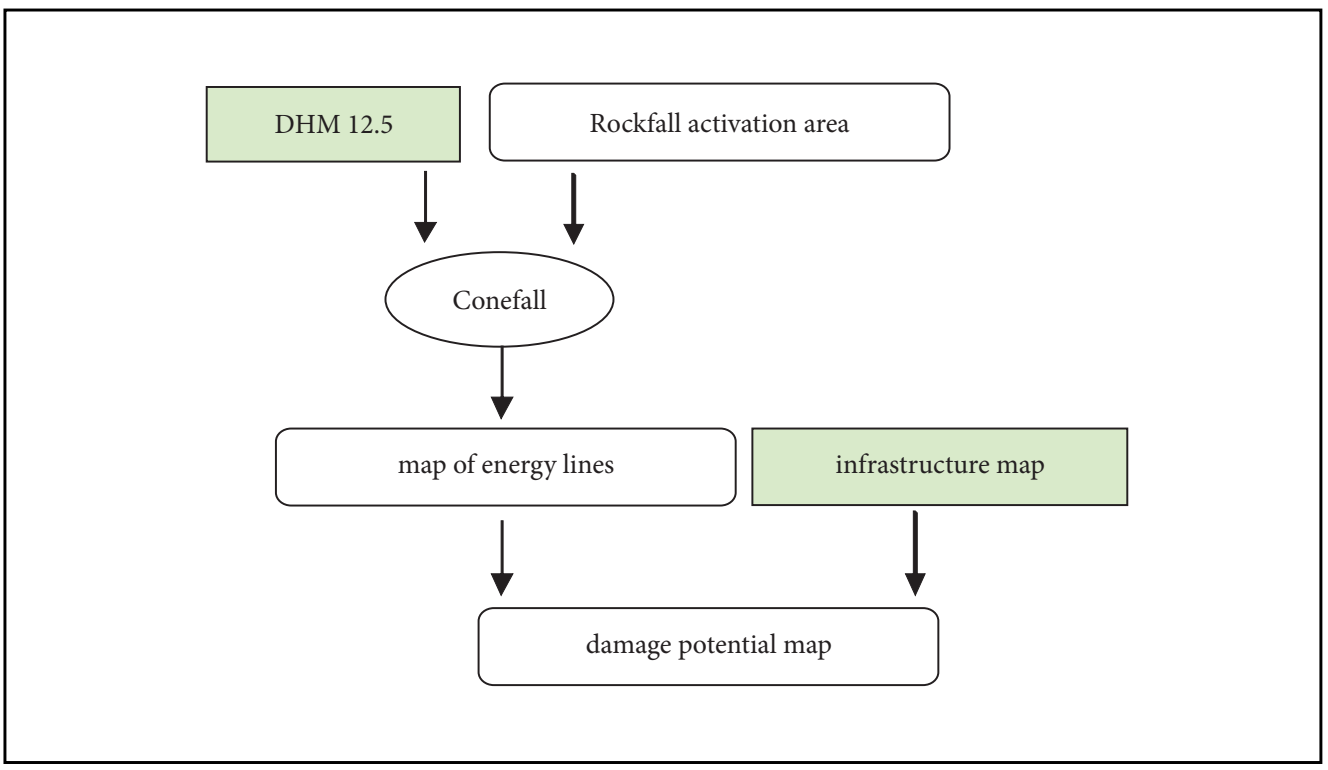

Figure 4: Process of damage potential map making. 
1
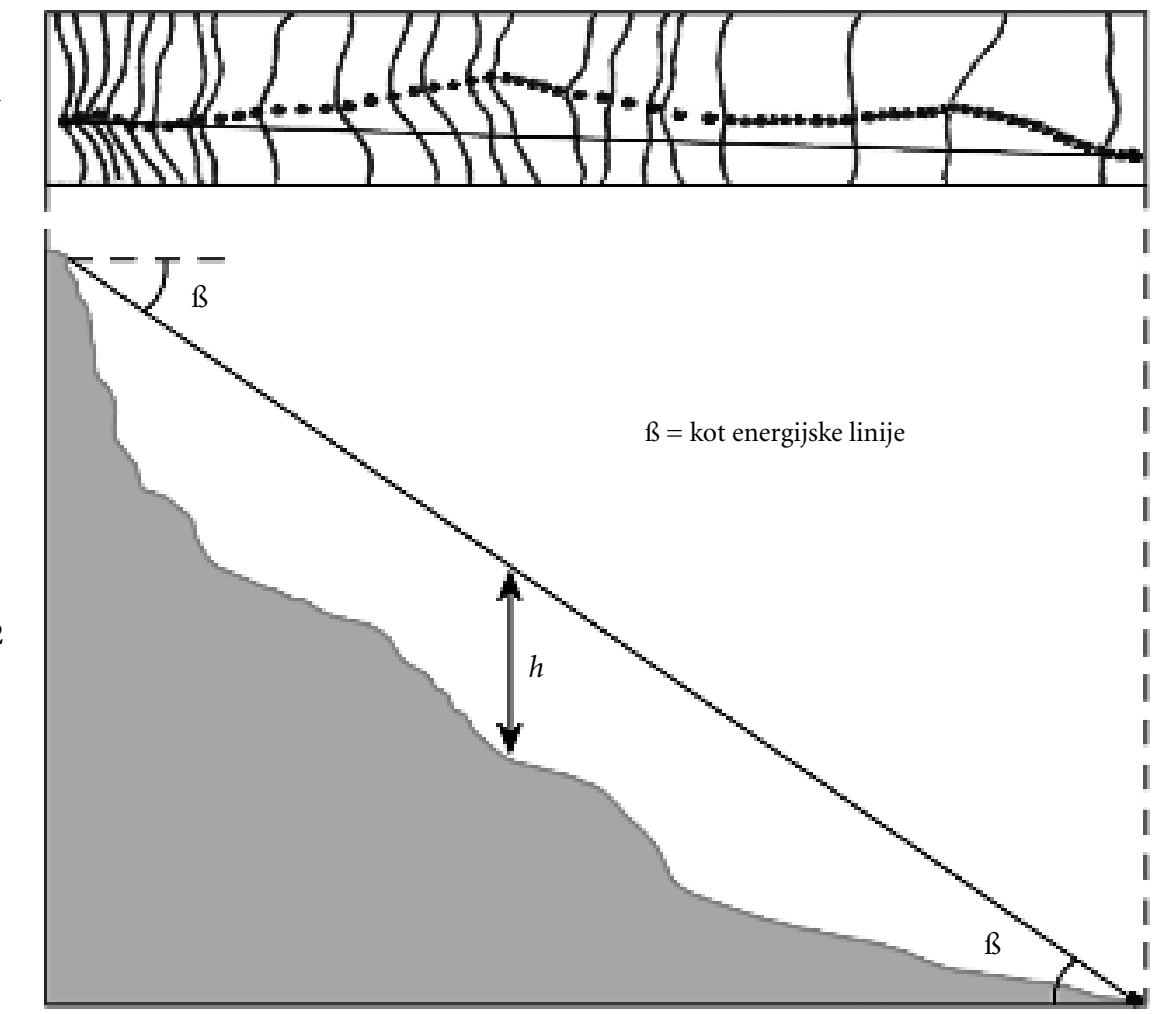

Figure 5: Presentation of the horizontal view on the rockfall travel direction (1) and the cross section of the terrain and rockfall travel line - 2 (Dorren 2003).

defined as rockfall activation areas. The geological map of Slovenia was also used in the treatment of forests and the forests growing on stable geological bedrock (limestone, massive or thick strata limestone, keratophyre or porphyry) were excluded.

The dispositional model results in the map of rockfall activation areas (Figure 3). The map of activation areas and DHM12.5 were used as input data in the Conefall 3D frictional model (Jaboyedoff 2003), which was used for calculating kinetic energy of rockfall masses.

Algorithms of frictional models operate on principles for calculating the maximal length of rockfall range in the field, according to the average friction ratio (Figure 5). The friction ratio is equal to the tangent of the inclination barycenter or the tangent of the rockfall travel angle. According to Heim (1932 quot. acc. to Petje et al. 2005), the travel angle is angle between horizontal plane and the line connecting the highest point of the scar in the rockfall source area and the most distant point where the rocks come to stop. From the viewpoint of the moving rockfall's energy, this means that the activated rockfall will travel down the slope all the way to the intersection of the relief line with the so-called energy line that runs from the rockfall activation area and forms angle $\beta$ with the horizontal (Dorren et al. 2005).

The Conefall program operates on the aforementioned principle; the difference is that the rockfall travel angle is not represented only as the angle between the horizontal plane and travel line, but is expressed in the form of angle of the cone that is projected vertically on the surface. In other words, an activated rockfall particle can reach any point on the surface located within a certain angle $(\beta)$ of the cone (Dorren et al. 2005). 


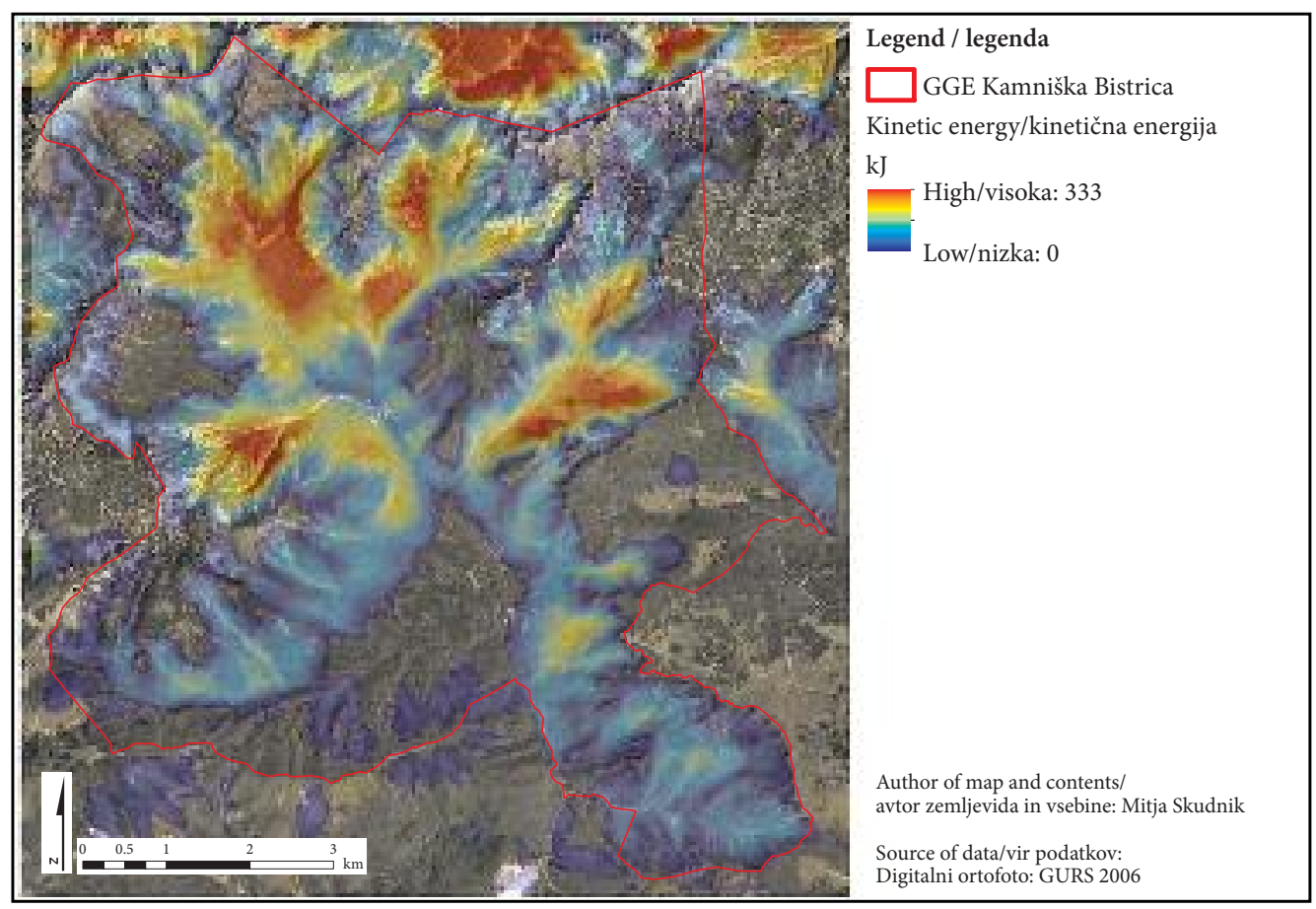

Figure 6: Rockfalls' kinetic energy calculated using the Conefal/ program.

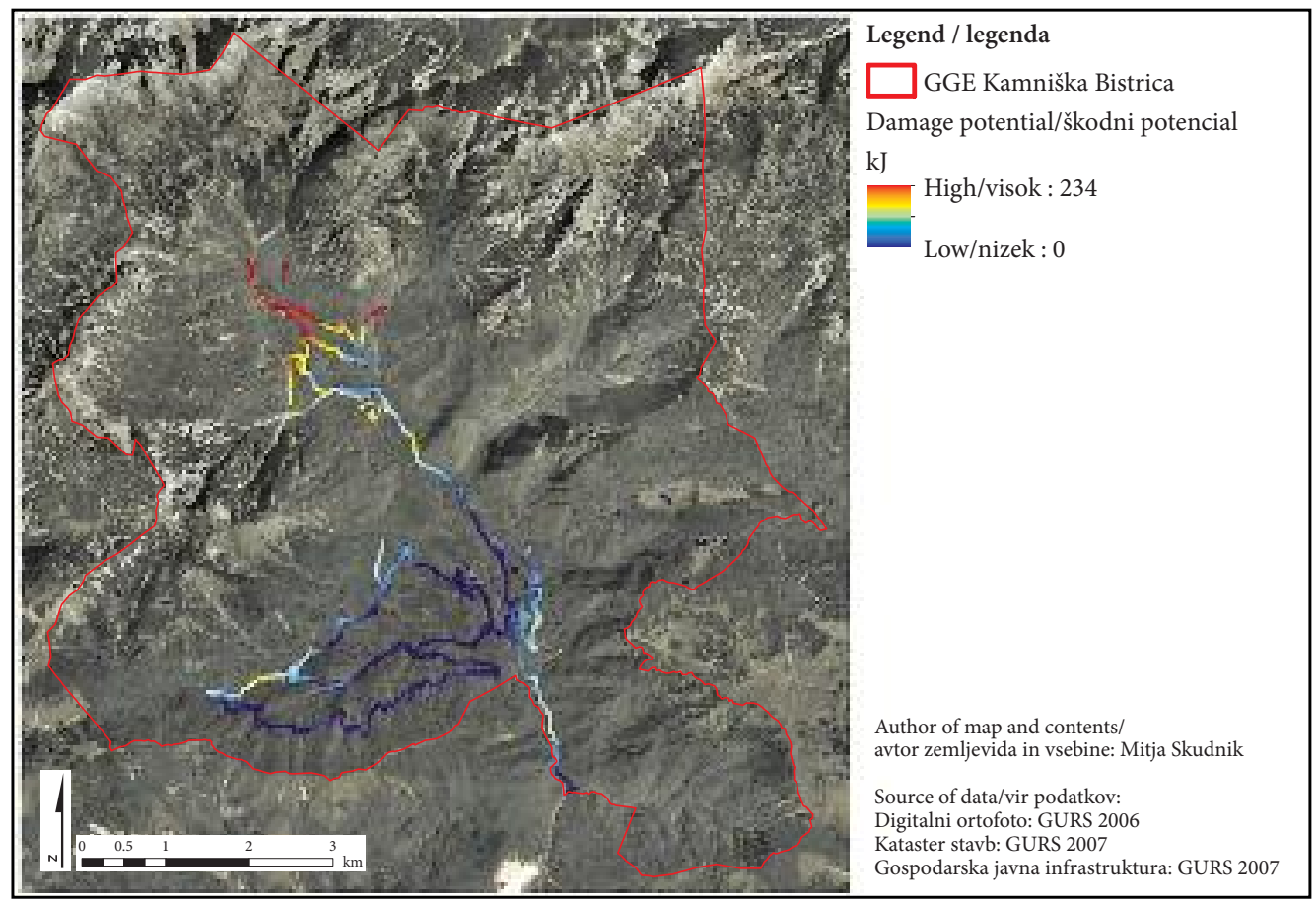

Figure 7: Map of damage potential, showing rockfalls' kinetic energy at impact on infrastructure, expressed in kJ. 


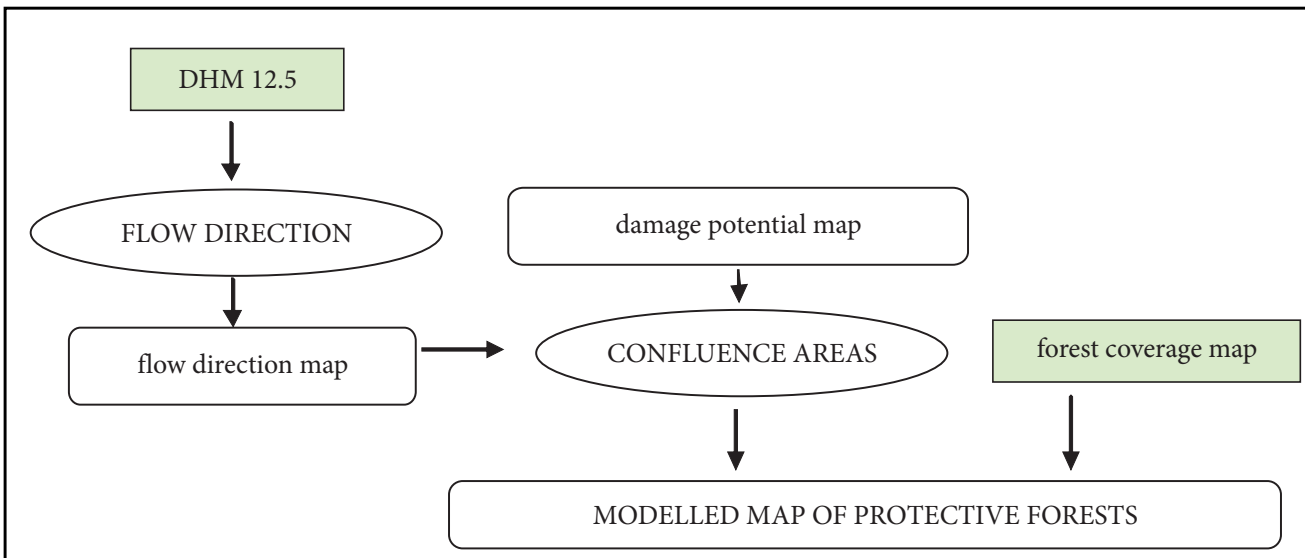

Figure 8: Process of protective forests mapping.

We used the motion angle $\beta 32^{\circ}$ or the dispersion angle for the calculation on the studied area. For calculating the kinetic energy of the rockfall, the average mass of the rockfall $(50 \mathrm{~kg})$ was also taken into account; it was determined with regard to the fact that the borderline volume between stones and rock is $20 \mathrm{dm}^{3}$ (Mikoš et al. 2004) and specific weight of the limestone is $2.300 \mathrm{~kg} / \mathrm{m}^{3}$ (Perry, 1967, quot. acc. to Mikoš et al. 2004).

The Conefall model results in the map of the rolling stones' kinetic energy (Figure 6). The higher the energy of the rockfall at the impact on the infrastructure is, the higher the damage on the object. Due to a possible deviation of assessment of the rockfall range, a buffer zone of $25 \mathrm{~m}$ was taken into account. The map of damage potential, or infrastructure potentially endangered by rockfall, was made using the intersection of rolling stones' kinetic energy map and the infrastructure map (Figure 7).

The forests in the rockfalls' paths representing a hurdle for these rockfalls, and therefore protect against them, were determined by the travel path model.

The map of fall direction was made on the basis of the DHM12.5 data layer. The "flow direction « tools operating on the principle of the D8 method (O'Callaghan, Mark 1984) were used in the ArcMap (ESRI 2010) program. The algorithm calculates the route of falling in the direction of maximal inclination from the central point. Using the aforementioned method, problems can arise on slopes where the fall directions should run in parallel, but merge into a single one (Petje et al. 2005).

The fall direction map and the damage potential map were used in mapping the rockfall accumulation areas. In doing so, the »watershed « tool was used in the ArcGIS program (ESRI 2010). For the program to be able to calculate these areas, the fall direction map must be included in the model, and the points for which we want to calculate the watershed or rockfall accumulation must be determined. Points of potentially endangered infrastructure (damage potential map) were used as accumulation points. In the way, the map of areas from which the rockfalls roll towards the objects (marked on the damage potential map) was made. The values of individual watersheds are equal to values of the points towards which the flow runs, and are equal to the kinetic energy of rockfalls at impact on infrastructure. An intersection of this map with the map of forests give us map of protective forests (Figure 9) that protect lower situated infrastructure against rockfalls (hereinafter referred to as modelled map of protective forests). On the basis of the rockfalls' kinetic energy value at impact, protective forests were classified into four categories:

- over $149 \mathrm{~kJ}$,

- over 94 to inclusively $149 \mathrm{~kJ}$,

- over 39 to inclusively $94 \mathrm{~kJ}$,

- to inclusively $39 \mathrm{~kJ}$. 


\section{Results}

\subsection{Modelled map of protective forests}

Protective forests $(2,842 \mathrm{ha})$ cover almost a half of the FMU's area. Other forests cover somewhat less than a quarter and non-forested areas less than a third of the area. Less than a third of protective forests is classified into the $4^{\text {th }}$, lowest category of emphasis, it is followed by a third of forests in the $3^{\text {rd }}$ category. The highest emphasis categories (the $1^{\text {st }}$ and $2^{\text {nd }}$ one) together comprise $23 \%$ of protective forests, located predominantly in the FMU's northern part, with the steepest and rockiest relief (Table 1).

Table 1: Protective forests' area by emphasis categories, with regard to the need for protection against rockfalls.

\begin{tabular}{lcc}
\hline Category & \multicolumn{2}{c}{ Area } \\
\cline { 2 - 3 } & ha & \% of the entire FMU area \\
\hline 1. & 458.0 & 16.1 \\
2. & 208.9 & 7.4 \\
3. & 925.2 & 32.6 \\
4. & $1,249.7$ & 44.0 \\
Total & $2,841.9$ & 100.0 \\
\hline
\end{tabular}

In all, $12 \%$ of all roads and $7 \%$ of all houses are located in the forests from the highest two categories (the $1^{\text {st }}$ and the $2^{\text {nd }}$ ). The facilities most exposed to damage are located in the northern part of the FMU, north of Žagana peč, in the Konec Valley, and Sivnica area. Here, the forest protects hunting cabins, bivouacs, and less frequented forest roads. Among the more frequented roads, the segment of the road between Predkonska and bottom station of cable car to Velika planina are protected. The $3^{\text {rd }}$ category of protec-

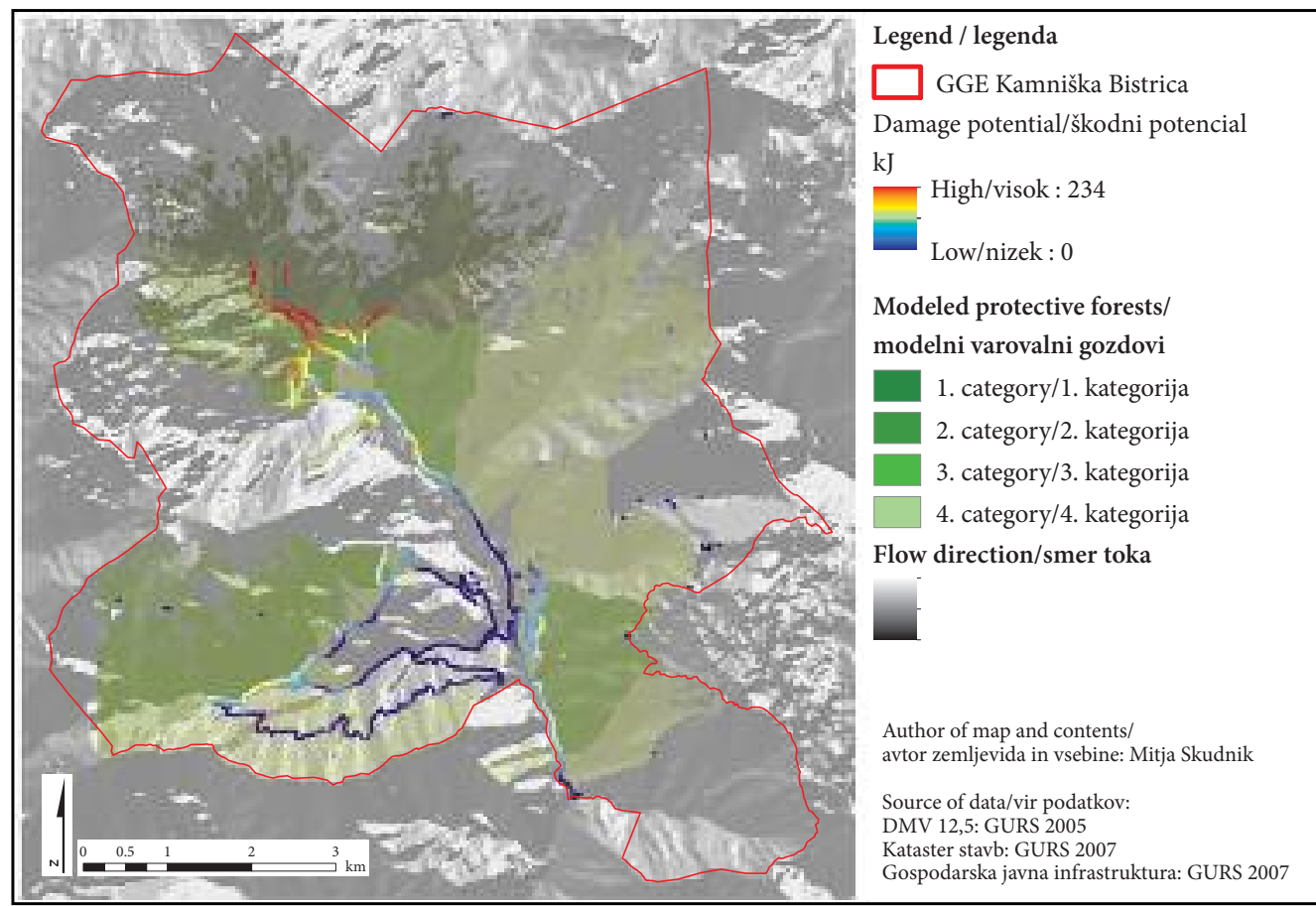

Figure 9: Protective forests determined by the model, four different emphasis levels with regard to protection of infrastructure against rockfalls. 


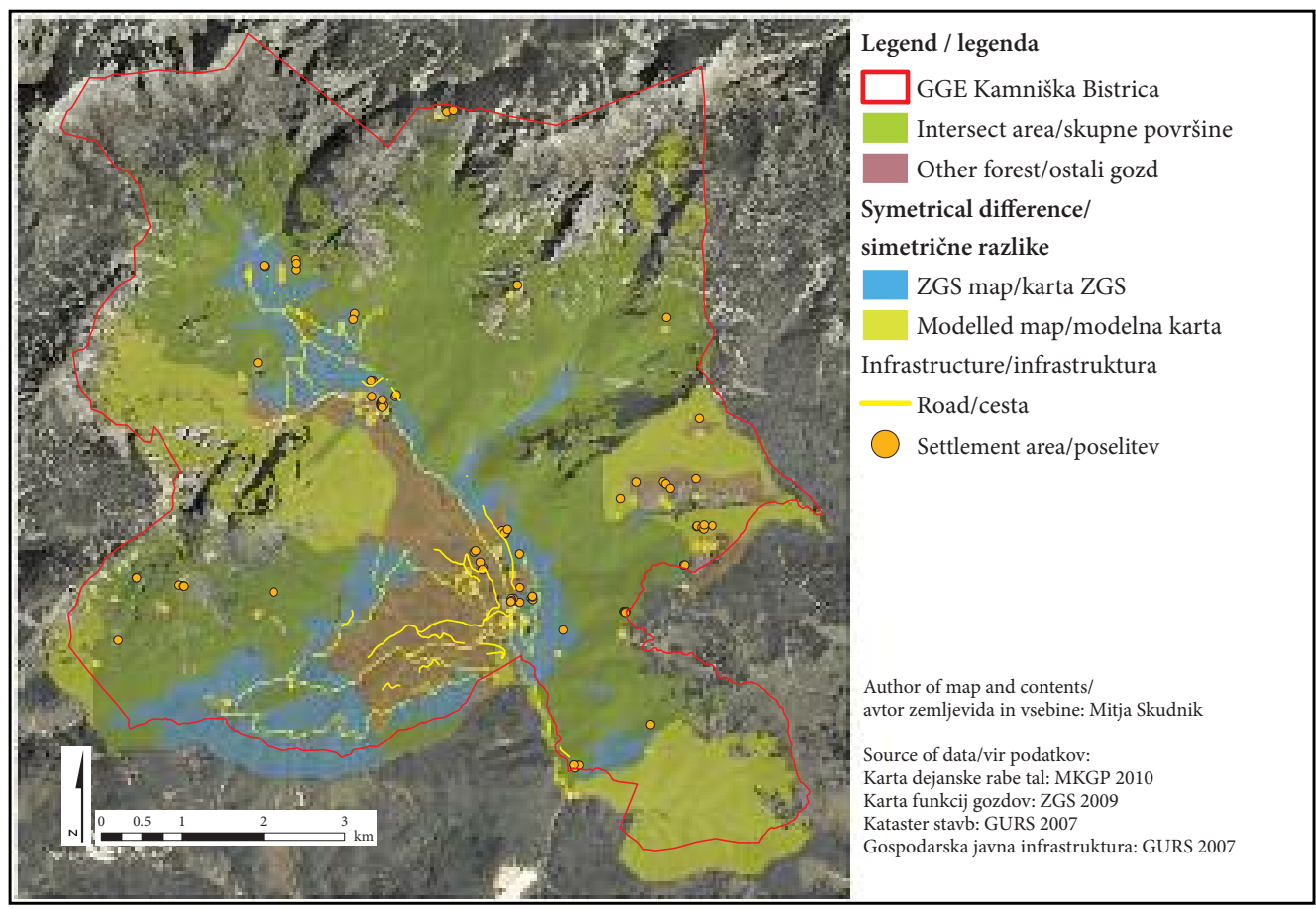

Figure 10: Intersection of the modelled map of protective forests and protective function map by SFS: areas, determined by the modelled map of protective forests and not determined by the protective function map by SFS (blue), areas determined by the map by SFS and not determined by the modelled map (light green), areas determined by both maps (dark green), and areas performing no protective function according to either of the maps (brown).

tive forests also comprises forests on the western part of the FMU (under Košutna and Dedec) and above the segment of the road between Mali Predoselj and Dom in Kamniška Bistrica. Dom in Kamniška Bistrica is also surrounded with forests of the $3^{\text {rd }}$ category. Protective forests of the $4^{\text {th }}$ category are located around houses Pri Jerinču and settlement Kopišče. Protective forests of all categories protect three quarters of all roads in FMU and $60 \%$ of all houses.

\subsection{A comparison and analysis of differences between protective function map by SFS and modelled map of protective forests}

The modelled map of protective forests protecting from rockfalls was compared to the map of protective function (ZGS 2009) (Figure 10). In doing so, only the forests with the $1^{\text {st }}$ level of protective function emphasis (amounting to 3,959 ha) were taken into account. For the sake of correct comparison, non-forested land was excluded, using the map of forests (MKGP 2010). The modelled map of protective forests, comprising 2,842 ha of land, and a segment of the protective function map by SFS, comprising 3,093 ha of land, were compared.

Table 2: Matrix of conformity of the modelled map of protective forests and protective function map by SFS

\begin{tabular}{lr}
\hline Protective forests & Area \\
\hline Both maps & $2,055 \mathrm{ha}(48.0 \%)$ \\
Modelled map of protective forests only & $776 \mathrm{ha}(18.1 \%)$ \\
Map of protective function by SFS only & $1,039 \mathrm{ha}(24.2 \%)$ \\
None & $415 \mathrm{ha}(9.7 \%)$ \\
Total area & $4,283 \mathrm{ha}(100 \%)$ \\
\hline
\end{tabular}


The maps match on $48 \%$ of the area of all forests, according to the modelled map of protective forests the majority $\left(1,480\right.$ ha) of them are in the $3^{\text {rd }}$ and $4^{\text {th }}$ category. The protective function map by SFS covers $90 \%$ of forests ( 413 of 458 ha) classified as the most important in rockfall protection by the modelled map $\left(1^{\text {st }}\right.$ category) and $77 \%$ of forests ( 160 of 209 ha) classified as the $2^{\text {nd }}$ category.

\section{Conclusion}

Models for determining areas endangered by rockfalls had already been checked in Slovenia, e.g. by: Zorn and Komac (2004), Petje et al. (2005), Čarman and Peternel (2010), and Đurović et al. (2005). Due to its simplicity, the applied 3D model can be used by people with good knowledge of tools in commercial GIS program environments.

On the test area, the model has shown that a half of the area is covered by forests protecting the lower situated infrastructure against rockfalls. According to the modelled map, the forests of primary importance for protection against rockfalls are situated at the very end of the Kamniška Bistrica valley, which was also observed by Gams and Bat (1983).

The reasons for the differences between the executed modelled map of protective forests and that protective function map which is being mapped and maintained by SFS according to the Regulation ... (2010) above all lie in the fact that the characteristics of a terrain (slope, erodibility) and vegetation association (can cover a larger area) are taken into account in mapping of the protective function of forests, while the fact that trees can also perform their protective function in lower positions where the terrain already becomes level is ignored. Forests representing obstacles on the path of potential rockfalls whose activation site is located outside of the forest space are not included in the group of forests with protective functions. The advantage of the modelled map of protective forests is its determining the areas where damage to property and danger for people can occur and excluding other areas. This enables performing silvicultural measures for enhancing protective functions only in those stands that actually perform this function. The protective function map by SFS, in contrast, excludes large areas where rockfalls can occur but cause no damage.

The deficiency of the modelled endangerment maps is their applicability on the regional level only; their direct applicability on the local level is minor. The reliability of maps made on the basis of GIS models depends on quality of the cartographic bases used and the applied method (Zorn and Komac 2004). In our case, sites of rockfall origins were determined on the basis of a topographic map with a scale of 1:50,000. We expect the accuracy of the precipitous rock faces to be substantially improved by using newer technologies of relief recording (e.g. lidar data; Kobler et al. 2006). The geological map also represents a limitation of use of similar models, since we only used a map with a scale of 1:250,000 (Buser 2010).

When modelling travel paths, it would make sense to include the characteristics of the slope into the model, since the friction force affects the rocks rolling downwards. The type of rock, slope texture, and characteristics of present vegetation significantly affect the roughness of the terrain and the reach of the rockfall (Dorren 2003). On the basis of forest inventory data, we could acquire information on forest structure, since the forest significantly affects the length of the rockfall path (Dorren et al. 2007).

The aim of the presented modelled map is to draw attention to the possibilities of process models' application in forest space and the use of similar models needed for location models of forests protecting against rockfalls. Thus, we would facilitate the work in the forestry profession and new methods would be introduced into mapping procedures for determining these forests. By using these models, we can predict paths of rockfalls and major damage locations more accurately, locate stands where silvicultural measures for function enhancing should be performed (e.g. leaving 1-m high stumps after felling, intentionally leaving felled trees on the rockfall path), and thus support damage protection.

\section{Acknowledgement}

The GIS model applied in the study is modified from the model developed in the framework of the EU project ProAlp, in which Forestry Institute of Slovenia took part in the years 2006-08. The research was also performed in the framework of the MANFRED/Alpine space project. The authors thank FSF for the map of forest functions. We thank our associates Andreja Ferreira, Ph. D., and Marko Kovač, Ph. D., and the reviewers for reviewing of our article and for their advice. 


\section{References}

Agliardi, F., Crosta, G.B. 2003: High resolution three-dimensional numerical modelling of rockfalls. International Journal of Rock Mechanics and Mining Sciences 40-4. Oxford. DOI: 10.1016/S1365-1609(03)00021-2. Brilly, M., Mikoš, M., Šraj, M. 1999: Vodne ujme: varstvo pred poplavami, erozijo in plazovi. Ljubljana. Buser, S. 2010: Geološka karta Slovenije 1:250.000. Ljubljana.

Čarman, M., Peternel, T. 2010: Skalni podori Stara gora pri Dvoru v občini Žuženberk. Geologija 53-2. Ljubljana. DOI: 10.5474/geologija.2010.016.

Dorren, L. K. A. 2003: A review of rockfall mechanics and modelling approaches. Progress in Physical Geography 27. London. DOI: 10.1191/0309133303pp359ra.

Dorren, L. K. A. 2006: Stem breakage of trees and energy dissipation during rockfall impacts. Tree physiology 26-1. Oxford.

Dorren, L. K. A., Berger, F., Jonsson, M., Krautblatter, M., Moelk, M., Stoffel, M., Wehrli, A. 2007: State of the art in rockfall - forest interactions. Journal forestier suisse 158. Zurich. DOI: 10.3188/szf.2007.0128.

Dorren, L. K. A., Berger, F., le Hir, C., Mermin, E., Tardif, P. 2005: Mechanisms, effects and management implications of rockfall in forests. Forest Ecology and Management 215-1-3. Amsterdam. DOI: 10.1016/j.foreco.2005.05.012.

Dorren, L. K.A., Seijmonsbergen, A. C. 2003: Comparison of three GIS-based models for predicting rockfall runout zones at a regional scale. Geomorphology 56-1-2. Amsterdam. DOI: 10.1016/S0169-555X(03)00045-X.

Duc, P., Perzl, F., Prskawetz, M., Dorren, L. K. A., Berger, F., Ginzler, C., Schneider, W., Schadauer, K. 2007: ProAlp - Development of harmonized indicators and estimation procedures for forests with protective functions against natural hazards in the alpine space. Wien.

Đurović, B., Ribičič, M., Mikoš, M. 2005: RHDM postopek analize potencialne ogroženosti zaradi odlomne nevarnosti. Geologija 48-1. Ljubljana.

ESRI. 2010: ArcMap 9.3.1 and Spatial Analyst. Institute E.S.R.

Gams, I., Bat, M. 1983: Metodologija kartiranja ogroženosti visokogorskih dolin. Naravne nesreče v Jugoslaviji s posebnim ozirom na metodologijo geografskega proučevanja. Ljubljana.

GeoZS. 2003: Osnovna geološka karta Slovenije 1:100.000. Geološki zavod Slovenije. Ljubljana.

GURS. 1999: Državna topografska karta 1:50.000. Geodetska Uprava Republike Slovenije. Ljubljana.

GURS. 2005: Digitalni model višin 12,5. Geodetska Uprava Republike Slovenije. Ljubljana.

GURS. 2006: Ortofoto. Geodetska Uprava Republike Slovenije. Ljubljana.

GURS. 2007a: Kataster stavb. Geodetska Uprava Republike Slovenije. Ljubljana.

GURS. 2007b: Zbirni kataster gospodarske javne infrastrukture. Geodetska Uprava Republike Slovenije. Ljubljana.

Guzzetti, F., Crosta, G., Detti, R., Agliardi, F. 2002: STONE: a computer program for the three-dimensional simulation of rock-falls. Computers \& Geosciences 28-9. Oxford. DOI: 10.1016/S0098-3004(02)00025-0.

Horvat, A., Maričič, V., Papež, J. 2005: Projekta Interreg III za območje Alp: NAB in NMF. Ujma 19. Ljubljana. Jaboyedoff, M. 2003: Conefall 1.0 - User's Guide. Lausanne.

Kobler, A., Pfeifer, N., Ogrinc, P., Todorovski, L., Oštir, K., Džeroski, S. 2006: Repetitive interpolation: A robust algorithm for DTM generation from Aerial Laser Scanner Data in forested terrain. Remote Sensing of Environment 108. New York. DOI: 10.1016/j.rse.2006.10.013

Kunc, K. 2008: Vpliv gospodarjenja na stabilnost varovalnih gozdov nad glavno cesto Godovič-Idrija, Univerza v Ljubljani, Biotehniška fakulteta, Oddelek za gozdarstvo in obnovljive gozdne vire. Ljubljana.

Marquínez, J., Menéndez Duarte, R., Farias, P., JiméNez Sánchez, M. 2003: Predictive GIS-Based Model of Rockfall Activity in Mountain Cliffs. Natural Hazards 30-3. Dordrecht. DOI: 10.1023/B:NHAZ.0000007170.21649.e1.

Mikoš, M., Batistič, P., Đurović, B., Humar, N., Janža, M., Komac, M., Petje, U., Ribičič, M., Vilfan, M. 2004: Metodologija za določanje ogroženih območij in način razvrščanja zemljišč v razrede ogroženosti zaradi zemeljskih plazov: končno poročilo. Ljubljana.

MKGP. 2010. Karta dejanske rabe tal, Ministrstvo za kmetijstvo gozdarstvo in prehrano.

O'Callaghan, J. F., Mark, D. M. 1984: The extraction of drainage networks from digital elevation data. Computer Vision, Graphics, and Image Processing 28-3. New York. DOI: 10.1016/s0734-189x(84)80011-0.

Petje, U., Ribičič, M., Mikoš, M. 2005: Computer simulation of stone falls and rockfalls. Acta geographica Slovenica 45-2. Ljubljana. DOI: 10.3986/AGS45204. 
Pravilnik o gozdnogospodarskih in gozdnogojitvenih načrtih. Uradni list Republike Slovenije 5/1998, 70/2006, 12/2008, 91/2010. Ljubljana.

Repolusk, P. 1991: Učinki poplav 1990 v zgornjem toku Kamniške Bistrice. Ujma 5. Ljubljana.

Stoffel, M. 2006: Assessing the protective effect of mountain forests against rockfall using a 3D simulation model. Forest Ecology and Management 225. Amsterdam. DOI: 10.1016/j.foreco.2005.12.030.

Uredba o varovalnih gozdovih in gozdovih s posebnim namenom $\mathrm{z}$ dopolnitvami. Uradni list Republike Slovenije 88/2005, 56/2007, 29/2009, 91/2010. Ljubljana.

ZGS. 2008: Priročnika za izdelavo gozdnogospodarskih načrtov. Ljubljana.

ZGS. 2009: Karta funkcij gozdov. Zavod za gozdove Slovenije. Ljubljana.

ZGS OE Ljubljana. 2009: GGN GGE Kamniška Bistrica 2009-2018. Ljubljana.

Zorn, M. 2002: Rockfalls in Slovene Alps. Acta geographica Slovenica 42. Ljubljana.

Zorn, M., Komac, B. 2004: Deterministic modeling of landslide and rockfall risk. Acta geographica Slovenica 44-2. Ljubljana. DOI: 10.3986/AGS44203. 



\title{
Uporaba 3D procesnega modela za določitev gozdov, ki varujejo pred skalnimi podori - primer Kamniške Bistrice
}

\author{
DOI: $10.3986 / A G S 51202$ \\ UDK: $630 \star 26: 551.435 .62(497.451)$ \\ 004.9:630*26(497.451)
}

COBISS: 1.01

IZVLEČEK: Na primeru gozdnogospodarske enote Kamniška Bistrica je predstavljen 3D procesni model za določanja gozdov, ki varujejo pred sklanimi podori. Modeliranje je potekalo z orodji ArcGIS 9.3.1; za izračun kinetične energije podorov smo uporabili trenjski model Conefall. Izdelano karto varovalnih gozdov smo primerjali s karto varovalne funkcije gozdov, ki jo je izdelal Zavod za gozdove Slovenije. Karta varovalne funkcije prekriva kar $90 \%$ gozdov, ki so bili z modelno karto uvrščeni med gozdove 1. kategorije. Ob upoštevanju celotne površine gozdov v gozdnogospodarski enoti, je med kartama 48 \% ujemanje. Do razhajanj prihaja v predvsem v višjih nadmorskih višinah, kjer karta varovalne funkcije vključuje rastišča ruševja in na nižjih nadmorskih višinah, kjer karta ne upošteva, da lahko gozdna drevesa opravljajo svojo varovalno funkcijo tudi nižje, kjer se sicer teren že izravna. Namen prispevka je opozoriti na možnosti uporabe modelov kot orodij za določitev gozdov, ki varujejo pred podori.

KLJUČNE BESEDE: gozdarstvo, fizična geografija, 3D procesno modeliranje, varovalna funkcija gozda, skalni podori, Kamniška Bistrica

Uredništvo je prejelo prispevek 17. februarja 2011.

NASLOVA:

Mitja Skudnik

Gozdarski inštitut Slovenije

Večna pot 2, SI - 1000 Ljubljana

E-pošta: mitja.skudnik@gozdis.si

\section{dr. Gal Kušar}

Gozdarski inštitut Slovenije

Večna pot 2, SI - 1000 Ljubljana

E-pošta: gal.kusar@gozdis.si

\section{Vsebina}

1 Uvod 269

$\begin{array}{ll}1.1 & \text { Podori in varovalna funkcija gozdov } 269\end{array}$

1.2 Metode določanja varovalne funkcije gozdov 269

1.2.1 Modeliranje v okolju GIS 269

2 Metode dela 270

2.1 Predstavitev testnega območja 270

2.2 Modeliranje in izdelava kart 270

2.2.1 Priprava podatkovnih slojev 270

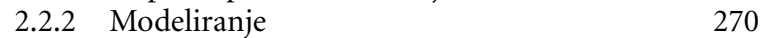

3 Rezultati 273

3.1 Modelna karta varovalnih gozdov 273

3.2 Primerjava in analiza razlik karte varovalne funkcije zgs in modelne karte varovalnih gozdov 274

$\begin{array}{lll}4 & \text { Sklep } & 274 \\ 5 & \text { Zahvala } & 275 \\ 6 & \text { Literatura } & 275\end{array}$




\section{Uvod}

\subsection{Podori in varovalna funkcija gozdov}

Na območjih z razgibanim reliefom so pogosti nevarni pojavi (hudourniške poplave, snežni plazovi, zemeljski usadi in plazovi, drobirski tokovi ter kamniti plazovi in skalni podori), ki omejujejo dejavnosti in ogrožajo premoženje (Brilly in ostali 1999; Horvat in ostali 2005; Zorn 2002; Dorren, Seijmonsbergen 2003; Kunc 2008). Članek obravnava le skalne podore (v nadaljevanju podore), ki jih podobno kot Zorn (2002), razume v širšem pomenu besede in pod pojmom skalni podor upošteva vse vrste porušitev (od manjšega krušenja kamenja do večjih porušitev posameznih skal) trdne kamnine na pobočjih, kjer gradivo prosto pada proti vznožju ne glede na količino premaknjenega gradiva.

Najpogostejši načini varovanja pred podori so tehnični ukrepi (varovalne mreže in zaščitne ograje). Izvedba ukrepov in vzdrževanje varovalnih objektov pa je drago (Dorren 2003), hkrati pa takšni objekti predstavljajo tujek $v$ naravnem okolju, vplivajo na naravne procese $\mathrm{v}$ ekosistemih ter motijo estetski vidik krajine. Gozd lahko nadomesti tehnične ukrepe, saj predstavlja ovire podorom. Kako uspešno gozd varuje, je odvisno od strukture gozda, drevesnih vrst, razvojne faze, podrasti, količine, razporeditve in strukture odmrlega drevja (Dorren 2006; Stoffel 2006). Na krepitev varovalne funkcije gozda se lahko vpliva $z$ ustreznimi gozdnogojitvenimi ukrepi, npr. s puščanjem visokih panjev ali z uravnavanjem sestojne zgradbe (ZGS OE Ljubljana 2009). Zaradi stroškov je te ukrepe smiselno izvajati le tam, kjer je varovalna funkcija resnično prisotna oz. potrebna. Izpolnjeni morajo biti pogoji in sicer mora obstajati:

- premoženje, ki ga je potrebno varovati,

- možnost nevarnega pojava, ki lahko ogrozi premoženje,

- gozd, ki lahko varuje premoženje.

\subsection{Metode določanja varovalne funkcije gozdov}

Pravilnik o gozdnogospodarskih in gozdnogojitvenih načrtih (1998) z dopolnitvami (2010) (Pravil nik ... 2010) razlikuje med gozdovi, ki opravljajo zaščitno funkcijo ter gozdovi, ki opravljajo funkcijo varovanja gozdnih zemljišč in sestojev. $V$ tem članku obravnavamo obe funkciji skupaj pod imenom varovalna funkcija, ki se razume kot vsaka vloga gozda, ki varuje ali ščiti premoženje pred podori.

Kartiranje funkcij opravljajo uslužbenci Zavoda za gozdove Slovenije (v nadaljevanju ZGS) na podlagi Pravilnika ... (2010) in navodil Priročnika za izdelavo gozdnogospodarskih načrtov (ZGS 2008), ki vsebuje merila za določanje funkcij pri različnih stopnjah poudarjenosti. Glavni kriteriji za ovrednotenje varovalne funkcije so opredeljene gozdne združbe, veliki nakloni, skalovitost, erodibilna in plazljiva matična podlaga. Pri ovrednotenju zaščitne funkcije pa strme brežine - veliki nakloni in prisotnost infrastrukturnih, stanovanjskih ali gospodarskih objektov. Pri določanju 1. stopnje poudarjenosti varovalne ali zaščitne funkcije je treba upoštevati tudi varovalne gozdove, določene z Uredbo o varovalnih gozdo vih in gozdovih s posebnim pomenom (Uredba ... 2005).

\subsubsection{Modeliranje v okolju GIS}

Za določitev površin, kjer se lahko pojavijo podori, so bili razviti modeli (Guzzetti in ostali 2002; Agliardi, Crosta 2003; Marquínez in ostali 2003; Zorn in Komac 2004; Petje in ostali 2005; Stoffel 2006), ki jih Petje in ostali (2005) delijo na dispozicijske in procesne, medtem ko jih Dorren (2003) deli na empirične oz. statistične, procesne in pa tiste, ki temeljijo na uporabi geografskih informacijskih sistemov (v nadaljevanju GIS-ov) oz. GIS-based. Dispozicijski modeli se uporabljajo za določitev mesta izvora podora, procesni pa za določitev poti gibanja skalnih mas.

Natančnejši geokodirani podatkovni sloji v zadnjih letih omogočajo uporabo tridimenzionalnih modelov (v nadaljevanju 3D), kjer uporabljajo predvsem razpoložljive rastrske in vektorske podatkovne sloje, za računanje poti gibanja pa se poslužujejo prej omenjenih procesnih modelov.

Sedanje metode kartiranja funkciji se kljub določenim merilom za kartiranje (ZGS 2008), zdijo preveč subjektivne, saj temeljijo na metodi terenskega kartiranja, ki je odvisna od izkušenj in znanja popisovalca. 
Cilj prispevka je predstaviti metodo 3D procesnega modela, prirejenega po modelu, ki je bil razvit v okviru EU projekta ProAlp (Duc in ostali 2007), ki lahko predstavlja pomoč gozdarski stroki pri kartiranju varovalne funkcije gozda.

\section{Metode dela}

\subsection{Predstavitev testnega območja}

Gozdnogospodarska enota (v nadaljevanju GGE) Kamniška Bistrica leži na severu Slovenije, površina enote je 6.108 ha, od tega 4.283 ha (70\%) poraščajo gozdovi (MKGP 2010). Osrednji del enote zajema zgornji del doline reke Kamniške Bistrice s hudourniškimi pritoki, ki leži v območju Kamniških Alp, za katerega so značilni strmi bregovi, ozke doline, številni jarki in močna skalovitost (ZGS OE Ljubljana 2009).

ZGS je varovalno funkcijo 1. stopnje določil na 3.957 ha gozdnega prostora. Zaščitno funkcijo 1. stopnje poudarjenosti opravljajo gozdovi na površini 43 ha, na strmih zahodnih pobočjih nad $2 \mathrm{~km}$ odsekom ceste Kamniška Bistrica, od južne meje GGE proti spodnji postaji nihalke na Veliko planino (slika 1). (ZGS OE Ljubljana 2009). Večina infrastrukture leži zunaj območji, kjer je določena 1. stopnja varovalne ali zaščitne funkcije.

Slika 1: GGE Kamniška Bistrica: Varovalna in zaščitna funkcija gozda.

Glej angleški del prispevka.

Iz preteklosti so v GGE že znane večje naravne nesreče. Gams in Bat (1983) omenjata, da se je pod Čmaževškim turnom sprožil podor, ki je razsul skalovje več sto metrov po vršaju, nekaj skal pa je preskočilo zaplate gozda in obtičalo več deset metrov daleč od vznožja pobočja. Novembra 1990 so zaradi kratkotrajnega, a močnega deževja močno narasli hudourniki in Kamniška Bistrica je poplavila. Takrat je bilo v zgornjem porečju Kamniške Bistrice zaradi hudournikov ali plazov poškodovanih 48 stanovanjskih objektov (Repolusk 1991).

\subsection{Modeliranje in izdelava kart}

\subsubsection{Priprava podatkovnih slojev}

Postopek modeliranja je potekal s programskim orodjem ArcGIS 9.3.1 (ESRI 2010). V model je bilo vključenih šest geokodiranih podatkovnih slojev:

- digitalni model višin natančnosti 12,5 metrov (v nadaljevanju DMV12,5) (GURS 2005),

- karta skalovitosti, ki je bila izdelana iz državne topografske karte v merilu 1:50.000 (GURS 1999). Sloj prikazuje linije in obrobe cest ter skalovita območja,

- karta cest iz zbirnega katastra gospodarske javne infrastrukture (v nadaljevanju GJI) (GURS 2007b),

- kataster stavb na dan 25.5.2007 (GURS 2007a),

- osnovna geološka karta Slovenije v merilu 1:100.000 (GeoZS 2003),

- karta dejanske rabe tal iz leta 2010 (MKGP 2010).

Za izdelavo karte dosega podorov je bilo uporabljeno programsko orodje Conefall (Jaboyedoff 2003), ki je bilo izbrano zaradi enostavnosti uporabe in omogoča uporabo digitalnih modelov višin različne natančnosti ter nima omejitve glede velikosti testne površine.

\subsubsection{Modeliranje}

Modelna karta varovalnih gozdov pred podori, je bila izdelana po 3D procesnem modelu, sestavljenem iz treh sklopov:

- dispozicijski model, katerega rezultat je karta območij sproščanja podorov,

- trenjski model, katerega rezultat je karta škodnega potenciala,

- model poti gibanja, katerega rezultat je modelna karta varovalnih gozdov.

Cilj dispozicijskega modela je bil s pomočjo obstoječih geokodiranih podatkovnih slojev določiti možna območja sproščanja podorov. 


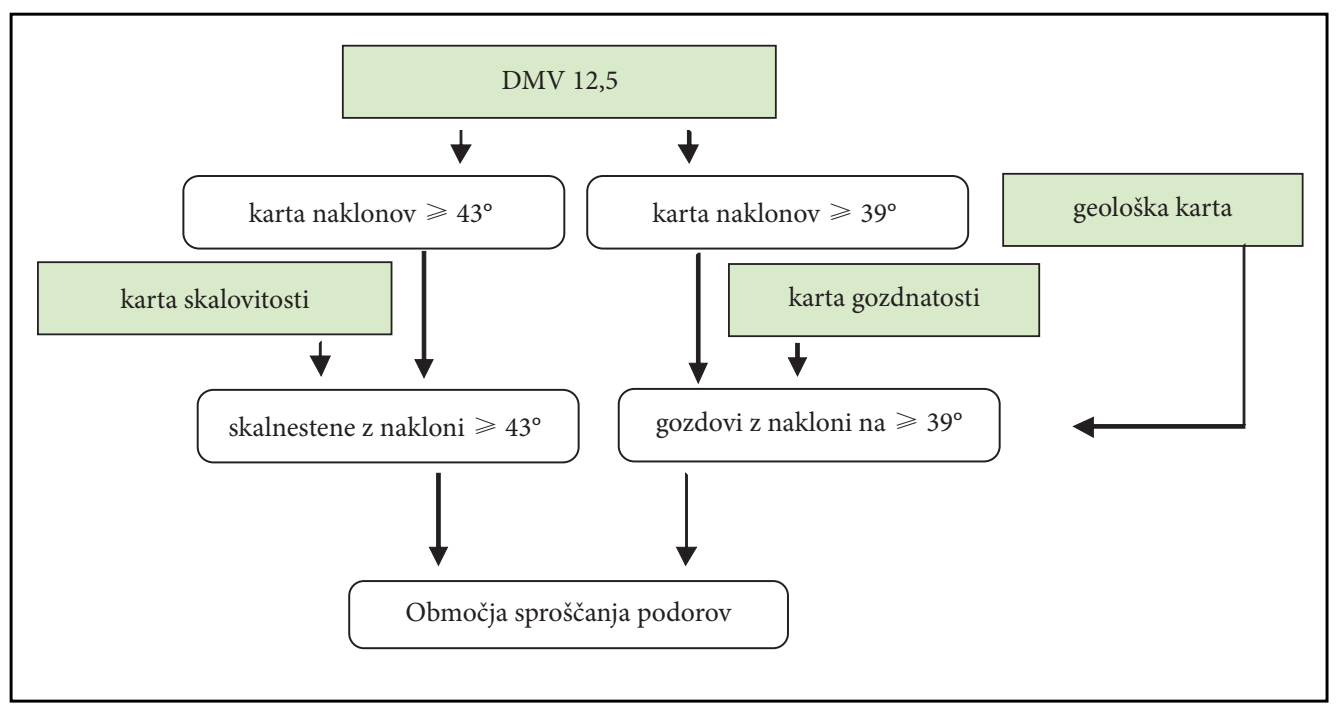

Slika 2: Postopek določitve območij sproščanja podorov.

Osnovni podatkovni sloj modela predstavlja DMV12,5. Iz karte, ki prikazuje linije cest in območja skalovij, se je izbrisalo ceste in se tako izdelalo karto skalovij. Kot območja sproščanja podorov se je definiralo neporasla območja strmih sten z nakloni $43^{\circ}$ ali več (Dorren in ostali 2005) in z gozdovi porasla območja z nakloni $39^{\circ}$ in več (Duc in ostali 2007). Pri obravnavi gozdov se je upoštevalo tudi geološko karto Slovenije tako, da se je izločilo gozdove, ki rastejo na stabilni geološki podlagi (apnenec, masivni ali debelo skladovni apnenec, keratofir, porfir ali porfirit).

Slika 3: Karta območij sproščanja podorov. Območja skalnih sten z nakloni $43^{\circ}$ in več (rumena) ter gozdovi z nakloni $39^{\circ}$ in več na labilni matični podlagi (zelena).

Glej angleški del prispevka.

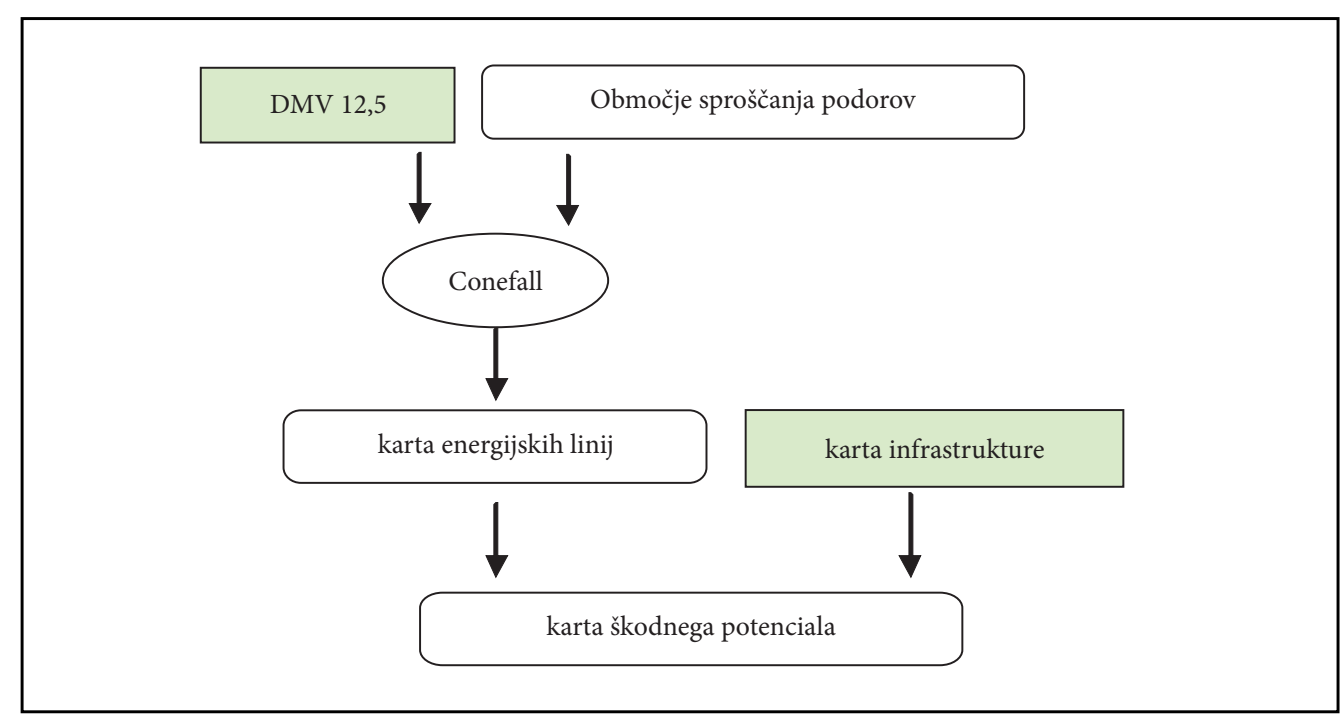

Slika 4: Postopek izdelave karte škodnega potenciala. 
Rezultat dispozicijskega modela je karta območij sproščanja podorov (slika 3). Karto območij sproščanja in DMV12,5 se je uporabilo kot vhodna podatka v 3D trenjski model Conefall (Jaboyedoff 2003), ki smo ga uporabili za izračune kinetične energije podornih mas.

Algoritmi trenjskih modelov delujejo na principih računanja maksimalne dolžine dosega podora na terenu glede na povprečen koeficient trenja (slika 5). Koeficient trenja je enak tangensu naklona težišča ali tangensu kota gibanja sklanega podora. Kot gibanja je po Heimu (1932 cit. po Petje in ostali 2005) kot med horizontalno ravnino in črto, ki povezuje najvišjo točko odlomnega roba izvora podora, in najbolj oddaljeno točko, kjer se skale ustavijo. Z vidika energije premikajočega se podora to pomeni, da bo sprožen podor potoval po pobočju vse do presečišča linije reliefa s tako imenovano energijsko linijo (ang. energy line), ki poteka od območja sproščanja podorov in tvori kot $\beta$ s horizontalo (Dorren in ostali 2005).

Slika 5: 1 - prikaz vodoravnega pogleda na smer gibanja podora, 2 - presek terena in linije gibanja podora (Dorren 2003).

Glej angleški del prispevka.

Program Conefall deluje na prej opisanem principu s to razliko, da kot gibanja podora ne predstavlja samo kot med horizontalno ravnino in linijo gibanja, ampak je izražen v obliki kota stožca, ki je vertikalno projiciran na površino. To pomeni, da delec podora, ki se sproži, lahko doseže katerokoli točko na površju, ki je znotraj določenega kota ( $\beta$ ) stožca (Dorren in ostali 2005). Za izračun na obravnavanem območju smo uporabili kot gibanja $\beta 32^{\circ}$ oziroma posipni kot. Za računanje kinetične energije podora se je upoštevala tudi povprečna masa podora $(50 \mathrm{~kg})$, pri določitvi katere se je upoštevalo, da je mejna prostornina med kamenjem in skalo $20 \mathrm{dm}^{3}$ (Mikoš in ostali 2004) in specifična teža apnenca $2.300 \mathrm{~kg} / \mathrm{m}^{3}$ (Perry 1967, cit. po Mikoš in ostali 2004).

Slika 6: S programom Conefall izračunana kinetična energija podorov.

Glej angleški del prispevka.

Rezultat Conefall modela je karta kinetične energije kotalečega kamenja (slika 6). Večja, kot je kinetična energija podora ob trku v infrastrukturo, večja je škoda na objektu. Zaradi možnega odstopanja ocen o dosegu podora se je pri karti infrastrukture upoštevalo tamponsko cono $25 \mathrm{~m}$. S presekom karte kinetične energije kotalečega kamenja s karto infrastrukture, smo izdelali karto škodnega potenciala ali potencialno ogrožene infrastrukture pred podori (slika 7).

Slika 7: Karta škodnega potenciala, ki prikazuje kinetično energijo podorov ob trku z infrastrukturo, izraženo v kJ.

Glej angleški del prispevka.

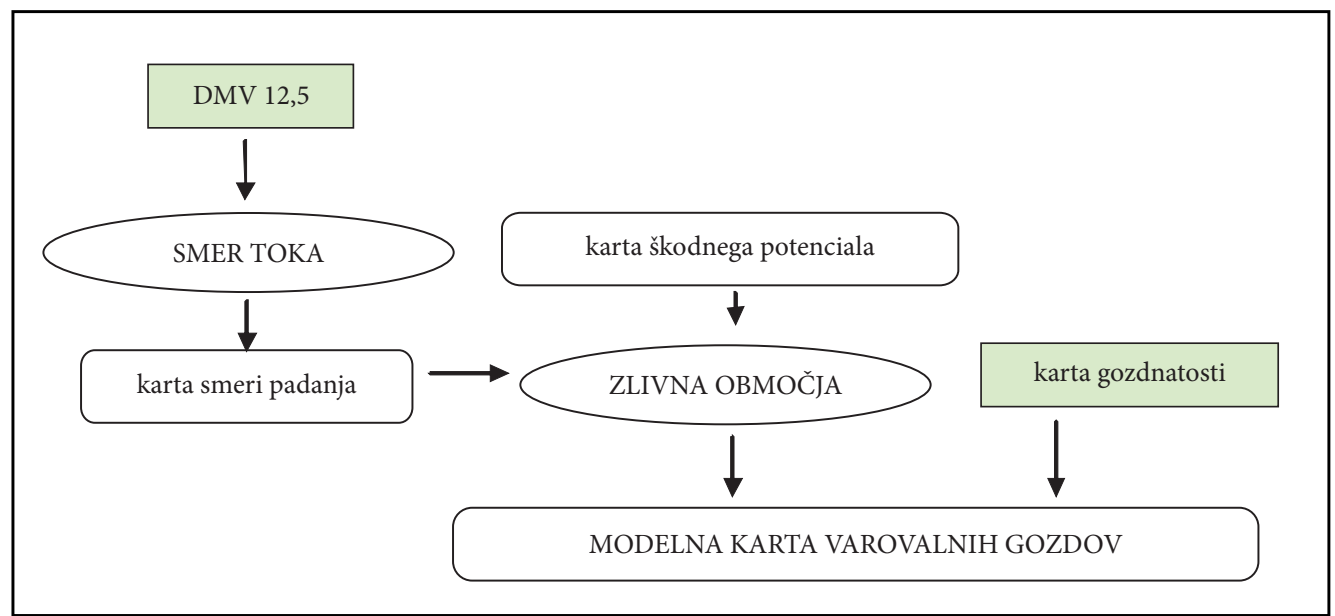

Slika 8: Postopek izdelave karte varovalnih gozdov. 
$\mathrm{Z}$ modelom poti gibanja se je določilo gozdove preko katerih poteka gibanje podorov, ki zato predstavljajo oviro podorom in zato varujejo pred podori.

Iz podatkovnega sloja DMV12,5 se je izdelalo karto smeri padanja. V programu ArcMap (ESRI 2010) se je uporabilo orodje smer toka (ang. flow direction), ki deluje po principu metode D8 (O'Callaghan, Mark 1984). Algoritem izračuna pot padanja v smeri največjega naklona iz centralne točke. Pri omenjeni metodi se lahko pri pobočjih, kjer bi morale potekati smeri padanja vzporedno, pojavijo težave, da se vzporedne smeri padanja združijo v eno (Petje in ostali 2005).

Karto smeri padanja in karto škodnega potenciala se je uporabilo za izdelavo karte območij stekanja podorov. Pri tem se je v programu ArcGIS uporabilo orodje za izdelavo prispevnih območij (ang. watershed) (ESRI 2010). Da lahko program izračuna ta območja, je potrebno v model vključiti karto smeri padanja in določiti točke, za katere se želi izračunati prispevno območje oz. stekanje podorov. Kot točke stekanja se je uporabilo točke potencialno ogrožene infrastrukture (karto škodnega potenciala). S tem se je izdelalo karto območij, iz katerih se podori kotalijo proti objektom označenim na karti škodnega potenciala. Vrednosti posameznih območij stekanja so enake vrednostim točk, h katerim poteka stekanje in so enake količini kinetične energije podora ob trku v infrastrukturni objekt. Po preseku te karte s karto gozdov se je dobilo karto varovalnih gozdov (slika 9), ki ščitijo nižje ležečo infrastrukturo pred podori (v nadaljevanju: modelna karta varovalnih gozdov). Varovalne gozdove se je na podlagi vrednosti kinetične energije podora ob trku razvrstilo $\mathrm{v}$ štiri kategorije:

- $1 . \operatorname{nad} 149 \mathrm{~kJ}$,

- 2. nad 94 do vključno $149 \mathrm{~kJ}$,

- 3. nad 39 do vključno $94 \mathrm{~kJ}$,

- 4. do vključno $39 \mathrm{~kJ}$.

\section{Rezultati}

\subsection{Modelna karta varovalnih gozdov}

Varovalni gozdovi (2.842 ha) pokrivajo skoraj polovico površine GGE. Ostali gozdovi pokrivajo slabo četrtino, slabo tretjino pa negozdne površine. Med varovalnimi gozdovi jih je slaba polovica uvrščenih v 4., najnižjo kategorijo poudarjenosti, sledi ji tretjina gozdov s 3. kategorijo. Najvišji kategoriji poudarjenosti (1. in 2.) ima skupaj $23 \%$ varovalnih gozdov, ti se nahajajo predvsem v severnem delu GGE, kjer je relief najbolj strm in skalovit (Preglednica 1).

Slika 9: Varovalni gozdovi določeni z modelom, s štirimi različnimi stopnjami poudarjenosti glede na varovanje infrastrukture pred podori. Glej angleški del prispevka.

Preglednica 1: Površina varovalnih gozdov po kategorijah poudarjenosti glede na potrebe po zaščiti pred podori.

\begin{tabular}{lcc}
\hline kategorija & \multicolumn{2}{c}{ površina } \\
\cline { 2 - 3 } & ha & $\%$ od vse površine GGE \\
\hline 1. & 458,0 & 16,1 \\
2. & 208,9 & 7,4 \\
3. & 925,2 & 32,6 \\
4. & 1249,7 & 44,0 \\
skupaj & 2841,9 & 100,0 \\
\hline
\end{tabular}

V gozdovih z najvišjima kategorijama (1. in 2.) je $12 \%$ vseh cest ter $7 \%$ vseh hiš. Poškodbam najbolj izpostavljeni objekti se nahajajo v severnem delu GGE in sicer severno od Žagane peči, v dolini Konec in na območju Sivnice. Tu gozd varuje lovske koče, bivake in manj prometne gozdne ceste. Od bolj prometnih cest varuje odsek ceste med Predkonjsko in spodnjo postajo nihalke na Veliko planino. V 3. kategorijo varovalnih gozdov so uvrščeni tudi gozdovi na zahodnem območju GGE (pod Košutno in Dedcem) in nad delom ceste med Malim Predosljem in Domom v Kamniški Bistrici. Tudi Dom v Kamniški Bistrici 
obdajajo gozdovi 3. kategorije. Varovalni gozdovi 4. kategorije se nahajajo okoli hiš Pri Jerinčku in zaselka Kopišča. Varovalni gozdovi vseh kategorij varujejo kar 3/4 vseh cest v GGE in $60 \%$ vseh hiš.

\subsection{Primerjava in analiza razlik karte varovalne funkcije ZGS in modelne karte varovalnih gozdov}

Modelno karto varovalnih gozdov, ki varujejo pred podori, se je primerjalo s karto varovalne funkcije (ZGS 2009) (slika 10). Pri tem se je upoštevalo le gozdove, kjer sta varovalna in zaščitna funkcija poudarjeni na 1. stopnji (površina teh gozdov je 3959 ha). Zaradi korektne primerjave se je s pomočjo karte gozdov (MKGP 2010) izločilo negozdna zemljišča. Primerjalo se je modelno karto varovalnih gozdov, ki zajema 2842 ha zemljišča in izsek karte varovalne funkcije ZGS, ki pokriva 3093 ha zemljišč.

Slika 10: Presek modelne karte varovalnih gozdov in karte varovalne funkcije ZGS: površine, ki jih določa modelna karta varovalnih gozdov in jih ne določa karta varovalne funkcije ZGS (modra), površine, ki jih določa karta ZGS in jih ne določa modelna karta (svetlo zelena), površine, ki jih opredeljujeta obe karti (temno zelena) in površine, ki ne opravljajo varovalne funkcije po nobeni od kart (rjava).

Glej angleški del prispevka.

Preglednica 2: Matrika ujemanja modelne karte varovalnih gozdov in karte varovalne funkcije ZGS

\begin{tabular}{lr}
\hline varovalni gozdovi & površina \\
\hline obe karti & 2055 ha $(48,0 \%)$ \\
samo modelna karta varovalnih gozdov & 776 ha $(18,1 \%)$ \\
samo karta varovalne funkcije ZGS & 1039 ha $(24,2 \%)$ \\
nobena & 415 ha $(9,7 \%)$ \\
skupaj površina & 4283 ha $(100 \%)$ \\
\hline
\end{tabular}

Karti se ujemata na $48 \%$ površine vseh gozdov, od tega jih je glede na modelno karto varovalnih gozdov velika večina ( 1480 ha) v 3. in 4 . kategoriji. Karta varovalne funkcije ZGS prekriva kar $90 \%$ gozdov (413 od 458 ha), ki so bili z modelno karto označeni kot najpomembnejši pri varovanju pred podori (1. kategorija) in $77 \%$ gozdov (160 od 209 ha), ki so bili označeni kot 2. kategorija.

\section{Sklep}

Modele za določitev območij, ki jih ogrožajo podori so v Sloveniji že preverili, npr.: Zorn in Komac (2004), Petje in ostali (2005), Čarman in Peternel (2010) ter Đurović in ostali (2005). Uporabljen 3D procesni model je, zaradi enostavnosti, mogoče uporabljati že ob boljšem poznavanju orodij v komercialnih GIS program skih okoljih.

Model je na testnem območju pokazal, da polovico površine območja prekrivajo gozdovi, ki varujejo nižje ležečo infrastrukturo pred podori. Pri varovanju pred podori so po modelni karti najpomembnejši gozdovi na samem koncu doline Kamniške Bistrice, kar sta na podlagi terenskega kartiranja ugotovila tudi Gams in Bat (1983).

Vzroki za razlike med izdelano modelno karto varovalnih gozdov in karto varovale funkcije, ki jo po navodilih Pravilnika ... (2010) izdeluje in vzdržuje Zavod za gozdove Slovenije, so predvsem v tem, da se pri kartiranju varovalne in zaščitne funkcije gozdov upoštevajo značilnosti terena (naklon, erodibilnost) in značilnosti vegetacijske združbe (lahko pokriva večje območje), medtem ko se ne upošteva, da drevesa opravljajo svojo varovalno funkcijo tudi v nižjih legah, kjer se sicer teren že izravna. Med gozdove z varovalno funkcijo tudi niso vključeni gozdovi, ki predstavljajo prepreke na poti možnih podorov, katerih mesto proženja se nahaja izven gozdnega prostora. Prednost modelne karte varovalnih gozdov je v tem, da dolo ča območja, kjer lahko pride do škod premoženja in nevarnosti za ljudi, ostala območja pa izloča. S tem je omogočeno izvajanje gozdnogojitvenih ukrepov za krepitev varovalne funkcije le v tistih sestojih, ki to funkcijo dejansko opravljajo. Nasprotno pa karta varovalne funkcije ZGS izloča velika območja, kjer do podorov sicer lahko prihaja, vendar ti ne povzročajo škode. 
Pomanjkljivost modelnih karte ogroženosti je, da so uporabne le na regionalni ravni, na krajevni ravni pa je njihova neposredna uporabnost majhna. Zanesljivost kart, ki nastanejo na podlagi GIS modelov, je odvisna od kakovosti uporabljenih kartografskih podlag in uporabljene metode (Zorn in Komac 2004). V našem primeru so bila izvorna območja podorov določena na podlagi topografske karte v merilu 1:50.000. Pričakujemo, da se bo natančnost določanja območij prepadnih sten bistveno izboljšala z uporabo novejših tehnologij snemanja reliefa (npr. lidarskih podatkov; Kobler in ostali 2006). Omejitev pri uporabi podobnih modelov je tudi geološka karta, saj razpolagamo le s karto z merilom kartiranja $1: 250.000$ (Buser 2010).

Pri modeliranju poti gibanja bi bilo zaradi sile trenja, ki vpliva na skalni blok ob kotaljenju navzdol, smiselno v modelu upoštevati tudi lastnosti pobočja. Vrsta kamnine, razbrazdanost pobočja in značilnosti prisotne vegetacije namreč pomembno vplivajo hrapavost terena in na doseg podora (Dorren 2003). Na podlagi podatkov gozdne inventure bi lahko pridobili informacije o strukturi gozda, saj gozd značilno vpliva na dolžino poti podora (Dorren in ostali 2007).

Namen prikazane modelne karte je opozoriti na možnosti uporabe procesnih modelov v gozdnem prostoru in uporabe podobnih modelov za potrebe ocen lokacij gozdov, ki varujejo pred podori. S tem bi olajšali delo gozdarski stroki, v postopke kartiranja pa bi se vpeljalo nove metode za določanje teh goz dov. S pomočjo modelov lahko bolje napovedujemo poti podorov in mesta največjih škod in tako lociramo sestoje, v katerih naj se izvaja gozdnogojitvene ukrepe za krepitev funkcij (npr. puščanje $1 \mathrm{~m}$ visokih panjev pri sečnji, namensko puščanje posekanih dreves na poti skalnih podorov) in s tem storiti veliko za preprečevanje škod.

\section{Zahvala}

V raziskavi uporabljen GIS model je prirejen po modelu, razvitem v okviru EU projekta ProAlp in v katerem je Gozdarski inštitut Slovenije sodeloval v letih 2006-08. Raziskava je potekal tudi v okviru projekta MANFRED/Alpski prostor. Avtorja se ZGS zahvaljujeva za karto funkcij gozdov. Zahvaljujeva se sodelavcema dr. Andreji Ferreira in dr. Marku Kovaču ter recenzentom za pregled članka in koristne nasvete.

\section{Literatura}

Glej angleški del prispevka. 